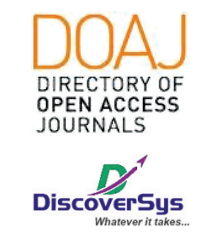

Published by DiscoverSys

\title{
Faktor penyebab infertilitas pasien program IVF (In Vitro Fertilization) di Klinik Graha Tunjung Rsup Sanglah
}

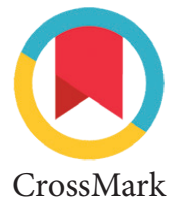

\author{
Ni Wayan Ariati Trisna Dewi, ${ }^{1 *}$ Anom Suardika, ${ }^{2}$ Ryan Saktika Mulyana ${ }^{2}$
}

\section{ABSTRACT}

Introduction: Infertility is the inability to get pregnant after 12 months or more without using contraception and is primary where the couple fails to get a pregnancy to continue the offspring. Infertility can be caused by factors of women, men or both. Around 50-80 million couples experience infertility in the world, infertility in developing countries is higher, which is around $30 \%$, compared to developed countries, only $5-8 \%$.

Method: This research is a cross-sectional descriptive study. The source of the data comes from secondary data, namely medical records of patients experiencing infertility at the clinic visiting Sanglah Hospital for the period January 2016-December 2017. Data collection was taken by the Total Sampling method. The distribution of research variables is in women with tubal, uterine and ovarian factors whereas in men it is sperm factor.
Result: Infertility events at Sanglah General Hospital Denpasar in January 2016 -December 2017 were 38 cases. In women, the factor of one non-patent tube were 4 cases (25.0\%), and respondents with both non-patent tubes were 12 cases (75.0\%). Ovarian factor abnormalities, Endometrioma were 2 cases (12.5\%). There were no cases of Uterine factor abnormalities in Women. Infertility in men based on sperm factors: 1 case oligozoospermia (5.6\%), Asthenozoospermia 2 cases (11.1\%), Teratozoospermia 1 case (5.6\%), Oligo Astheno Teratozoospermia 11 cases (61.1\%) and Azoospermia 3 cases (16.7\%).

Conclusion: The highest factor of infertility in women is abnormalities in the tube, both tubal non-patent. The highest cause of infertility in men is an abnormality in sperm, Oligo-AsthenoTeratozoospermia.

Keywords: infertility, causal factors, IVF program

Cite This Article: Dewi, N.W.A.T., Suardika, A., Mulyana, R.S. 2019. Faktor penyebab infertilitas pasien program IVF (In Vitro Fertilization) di Klinik Graha Tunjung Rsup Sanglah. Intisari Sains Medis 10(3): 741-745. D0I: 10.15562/ism.v10i3.421

\section{ABSTRAK}

Latar Belakang: Infertilitas adalah tidak mampu untuk hamil sesudah 12 bulan atau lebih tanpa menggunakan kontrasepsi dan bersifat primer dimana pasangan yang gagal untuk mendapatkan kehamilan untuk meneruskan keturunan. Infertilitas dapat disebabkan oleh faktor perempuan, laki-laki maupun keduanya. Sekitar 50-80 juta pasangan mengalami infertilitas di dunia, infertilitas di negara berkembang terjadi lebih tinggi yaitu sekitar $30 \%$, di bandingkan negara maju hanya 5-8\%.

Metode: Penelitian ini merupakan suatu penelitian deskriptif cross sectional, Sumber data berasal dari data sekunder yaitu rekam medis pasien yang mengalami infertilitas di klinik graha tunjung RSUP Sanglah periode Januari 2016 -Desember 2017. Pengambilan data di ambil dengan metode Total Sampling. Distribusi variabel penelitian yaitu pada perempuan dengan faktor tuba, uterus dan ovarium sedangkan pada laki-laki yaitu faktor sperma.
Hasil: Kejadian infertilitas di RSUP Sanglah Denpasar periode Januari 2016 -Desember 2017 sebanyak 38 kasus. Pada perempuan yaitu faktor satu tuba non-paten sebanyak 4 kasus $(25,0 \%)$, dan responden dengan kedua tuba non-paten sejumlah 12 kasus (75,0\%). Kasus denghan kelainan Faktor ovarium, yaitu Endometrioma sebanyak 2 kasus (12,5\%). Tidak didapatkan kasus dengan kelainan faktor Uterus pada Perempuan. Infertilitas pada laki-laki berdasarkan faktor sperma: oligozoospermia 1 kasus (5,6\%), Asthenozoospermia 2 kasus (11,1\%), Teratozoospermia 1 kasus (5,6\%), Oligo Astheno Teratozoospermia 11 kasus $(61,1 \%)$ dan Azoospermia 3 kasus $(16,7 \%)$.

Simpulan: Faktor penyebbab infertilitas pada perempuan yang paling tinggi adalah kelainan pada tuba yaitu, kedua tuba non patten. Sedangkann penyebab infertilitas paling tinggi pada laki-laki yaitu kelainan pada sperma Oligo Astheno Teratozoospermia.
Ni Wayan Ariati Trisna Dewi, Program Studi Pendidikan Dokter ariatitrisnadewi19@gmail.com

Diterima: 04-03-2019

Disetujui: 08-11-2019

Diterbitkan: 01-12-2019
Kata kunci: infertilitas, faktor penyebab, program IVF

Cite Pasal Ini: Dewi, N.W.A.T., Suardika, A., Mulyana, R.S. 2019. Faktor penyebab infertilitas pasien program IVF (In Vitro Fertilization) di Klinik Graha Tunjung Rsup Sanglah. Intisari Sains Medis 10(3): 741-745. D0I: 10.15562/ism.v10i3.421 


\section{PENDAHULUAN}

Infertilitas adalah ketidakmampuan untuk hamil sesudah 12 bulan atau lebih tanpa menggunakan kontrasepsi dan bersifat primer dimana pasangan yang gagal untuk mendapakan kehamilan untuk meneruskan keturunan. Infertilitas dapat disebabkan oleh faktor perempuan, laki-laki, maupun keduanya. Infertilitas dapat juga tidak diketahui penyebabnya, dikenal dengan istilah Infertilitas idiopatik. Masalah infertilitas dapat memberikan dampak besar, selain menyebabkan masalah medis, infertilitas juga dapat menyebabkan masalah ekonomi maupun psikologis. Secara garis besar, pasangan infertilitas akan menjalani proses panjang dari evaluasi dan pengobatan, proses ini dapat menjadi beban fisik dan psikologis bagi pasangan infertilitas. ${ }^{1,2}$

Sekitar 50-80 juta pasangan mengalami infertilitas di dunia, infertilitas di negara berkembang terjadi lebih tinggi yaitu sekitar $30 \%$, di bandingkan negara maju hanya 5-8\%. Prevalensi infertilitas di Eropa angka kejadiannya mencapai $14 \%$, sedangakn di Asia yaitu 30,8\%, di Kamboja 10\% dan di Indonesia sendiri, $21,3 \%$ infertilitas. $^{3}$

Kondisi yang menyebabkan infertilitas dari faktor istri $65 \%$, faktor suami $20 \%$, kondisi lainya yang tidak diketahui $15 \%$. Suatu penelitian menunjukkan penyebab infertilitas terkait dengan permasalahan dari pihak istri adalah tuba $(27,4 \%)$, masalah menstruasi (20\%), uterus $(9,1 \%)$, ovarium $(3,6 \%)$, kelainan seksual (2,7\%). Angka kejadian infertilitas pada wanita terjadi pada berbagai rentang umur, 20 -29 tahun (64,5\%), 30-39 tahun (20\%), 40-49 tahun (11,8\%), dan di atas 50 tahun $(3,7 \%) .{ }^{4}$ Infertilitas Primer adalah pasangan yang belum pernah hamil pada wanita yang telah berkeluarga meskipun hubungan seksual dilakukan secara teratur tanpa perlindungan kontrasepsi untuk selang waktu paling kurang 12 bulan. Infertilitas Sekunder adalah tidak terdapat kehamilan setelah berusaha dalam waktu 1 tahun atau lebih pada seorang wanita yang telah berkeluarga dengan hubungan seksual secara teratur tanpa perlindungan kontrasepsi, akan tetapi sebelumnya pernah hamil. ${ }^{5}$ Upaya pertolongan dan pengobatan untuk masalah infertilitas ada beberapa alternatif yaitu salah satunya adalah bayi tabung atau IVF (In Vitro Fertilization), Fertilisasi dapat diartikan pembuahan, sedangkan In Vitro adalah di luar. Jadi Fertilisasi In Vitro adalah suatu proses pembuahan sel telur oleh sel sperma diluar tubuh wanita, In Vitro (di dalam gelas kaca). ${ }^{6}$

Banyaknya faktor-faktor penyebab Infertilitas di RSUP Sanglah baik itu oleh faktor pria maupun wanita, maka dari itu perlu dilakukan pencarian apakah faktor-faktor penyebab paling tinggi kasus infertilitas serta penanganannya. Kasus Infertilitas ini diangkat sebagai topik skripsi tahap III karena ingin melihat dan mengetahui penyebab terjadinya infertilitas dan dari faktor-faktor apa saja yang mempengaruhi terjadinya infertilitas. Dengan mengetahui faktor penyebab Infertilitas diharapkan dapat mengurangi serta menekan frekuensi terjadinya infertilitas, baik itu dari faktor pria maupun wanita.

Bayi Tabung atau pembuahan In Vitro Fertilisation (IVF) adalah sebuah teknik pembuahan dimana sel telur (ovum) dibuahi diluar, Bayi Tabung adalah salah satu metode untuk mengatasi masalah infertilitas ketika metode lainnya tidak berhasil. 6,7

\section{METODE}

Penelitian ini merupakan penelitian deskriptif dengan desain penelitian cross-sectional (potong lintang) yang bertujuan untuk menggambarkan faktor penyebab infertilitas baik pada pria maupun wanita yang dapat memperhambat kehamilan. Penelitian ini dilakukan di Klinik Graha Tunjung RSUP Sanglah pada bulan Oktober 2018 sampai dengan November 2018. Sampel penelitian ini adalah pasangan yang ada di RSUP Sanglah baik pria maupun wanita yang terdiagnosis pasangan infertilitas. Kriteria inklusi sample adalah pasangan infertilitas yang terdiagnosis mengalami infertilitas di Rumah Sakit Umum Pusat Sanglah Denpasar, periode 1 Januari 2016 hingga 31 Desember 2017, rekam medis yang lengkap. Kriteria ekslusi adalah Pasien infertilitas dengan catatan rekam medis yang tidak lengkap. 38 sampel diperoleh dengan teknik total sampling.

Variabel-variabel yang diteliti dalam penelitian ini adalah faktor infertilitas pada perempuan yang meliputi faktor tuba (satu tuba non-paten, dua tuba non-paten), faktor uterus, faktor ovarium. Sedangkan pada laki-laki meliputi faktor sperma, oligozoospermia, asthenozoospermia, teratozoospermia, oligo astheno teratozoospermia, azoospermia. Variabel infertilitas yang tidak diketahui penyebabnya baik pada laki-laki dan perempuan juga diteliti dalam penelitian ini.

Penelitian ini menggunakan data sekunder pasangan infertilitas di RSUP Sanglah Denpasar. Data diperoleh secara retrospektif dari rekam medis pasien infertilitas pada periode 1 Januari 2016 hingga 31 Desember 2017. Data dianalisis menggunakan bantuan program SPSS, kemudian disajikan secara deskriptif dalam bentuk tabel dan diinterpretasikan.

\section{HASIL}

Responden dengan kelainan satu Tuba Non-Paten sebanyak 4 kasus $(25,0 \%)$, dan responden dengan 
Tabel 1 Karakteristik Penyebab Infertilitas pada pasien perempuan di Klinik Graha Tunjung RSUP Sanglah

\begin{tabular}{lc}
\hline Faktor Penyebab & $\mathbf{n}(\%)$ \\
\hline Tuba & \\
Satu Tuba Non-Paten & $4(25,0)$ \\
Dua Tuba Non-Paten & $12(75,0)$ \\
Ovarium & \\
Endometrioma & $2(12,5)$ \\
Tidak ada kelainan & $14(87,5)$ \\
Uterus & \\
Kelainan kongenital & $0(0)$ \\
Kelainan letak rahim & $0(0)$ \\
Tumor & $0(0)$ \\
Tidak ada kelainan anatomi & $16(100)$ \\
\hline
\end{tabular}

Tabel 2 Karakteristik Penyebab Infertilitas (Faktor Sperma) pada pasien laki-laki di Klinik Graha Tunjung RSUP Sanglah

\begin{tabular}{lc}
\hline Faktor Penyebab (Faktor Sperma) & $\mathbf{n}(\%)$ \\
\hline Oligozoospermia & $1(5,6)$ \\
Asthenozoospermia & $2(11,1)$ \\
Teratozoospermia & $1(5,6)$ \\
Oligo Astheno Teratozoospermia & $11(61,1)$ \\
Azoospermia & $3(16,7)$ \\
\hline
\end{tabular}

Tabel 3 Faktor Infertilitas tidak terjelaskan pada wanita di Klinik Graha Tunjung RSUP Sanglah

\begin{tabular}{lc}
\hline Infertilitas & $\mathbf{n}(\%)$ \\
\hline Tidak terjelaskan & $3(15,8)$ \\
Terjelaskan & $16(84,2)$ \\
\hline
\end{tabular}

Tabel 4 Faktor Infertilitas tidak terjelaskan pada pasien laki-laki di Klinik Graha Tunjung RSUP Sanglah

\begin{tabular}{lc}
\hline Infertilitas & $\mathbf{n}(\%)$ \\
\hline Tidak terjelaskan & $1(5,3)$ \\
Terjelaskan & $18(94,7)$ \\
\hline
\end{tabular}

Kedua Tuba Non-Paten sejumlah 12 kasus (75,0\%). Kelainan pada ovarium yaitu Endometrioma sejumlah 2 orang $(12,5 \%)$ dan perempuan yang tidak mengalami kelainan pada ovarium sejumlah 14 orang $(87,5 \%)$ (Tabel 1$)$.

Infertilitas pada laki-laki berdasarkan faktor sperma, yaitu oligozoospermia 1 kasus (5,6\%), Asthenozoospermia 2 kasus $(11,1 \%)$, Teratozoospermia 1 kasus (5,6\%), Oligo Astheno Teratozoospermia 11 kasus $(61,1 \%)$ dan Azoospermia 3 kasus (16,7\%) (Tabel 2).

Faktor infertilitas tidak terjelaskan pada wanita berjumlah 3 kasus, dengan persentase $(15,8 \%)$ dan faktor infertilitas yang dapat terjelaskan berjumlah
16 kasus infertilitas pada wanita dengan persentase $(84,2 \%)$ (Tabel 3). Faktor infertilitas tidak terjelaskan pada laki-laki berjumlah 1 kasus, dengan persentase $(5,3 \%)$ sedangkan faktor penyebab infertilitas yang dapat terjelaskan berjumlah 18 kasus dengan persentase (94,7\%) (Tabel 4).

\section{PEMBAHASAN}

Studi ini menunjukan bahwa pada 19 wanita yang diduga mengalami infertilitas, hanya 16 yang dapat dijelaskan alasannya sedangkan 3 lainnya belum dapat dijelaskan alasan infertilitasnya. Dari 16 orang dengan alasan infertilitas yang dapat dijelaskan, ditemukan 25\% mengalami gangguan pada salah satu tuba falopinya sedangkan $75 \%$ mengalami gangguan pada kedua tuba falopinya. Dalam studi ini, tidak ditemukan wanita dengan kelainan pada uterus dan hanya ada 2 wanita dengan endometrioma.

Studi yang dilakukan oleh Abrao dkk menyatakan bahwa 25-35\% wanita dengan infertilitas menunjukkan adanya keterlibatan tubopeeritoneal dengan kasus tersering adalah kerusakan tuba dan inflamasi pelvis. Oklusi tuba dapat terjadi pada $85 \%$ kasus keterlibatan tuba yang dapat disebabkan oleh adanya fibrosis paska infeksi, spasme ostiym tuba, endometrium yang tebal, serta penutupan tuba oleh penyebab yang tidak jelas. ${ }^{8}$ Berdasarkan Miller $\mathrm{dkk}$, penyebab infertilitas pada wanita yang terbanyak adalah kelainan ovulasi yaitu $40 \%$, disusul dengan adanya kelainan tuba yaitu $30 \%$, endometriosis $15 \%$, dan $10 \%$ sisanya adalah kelainan lainnya seperti faktor uterus ( $>3 \%$ ), fibroid, kelaianan kongenital uterus, polip, buruknya mukus servukal dan sinekia uterus. ${ }^{9}$

Studi ini menunjukan tidak ada kelainan ovulasi pada pasien, dan tidak ada pasien dengan kelainan uterus. Sebuah studi yang dilakukan oleh Bhattacharya dkk di United Kingdom menemukan bahwa $20 \%$ infertilitas pada perempuan tidak dapat dijelaskan penyebabnya, sedangkan $27 \%$ disebabkan oleh kegagalan ovulasi, 14\% disebabkan oleh kerusakan tuba, 5\% oleh endometriosis dan 5\% oleh kelainan lainnya. Kelainan tuba merupakan salah satu kelainan anatomis yang paling ditemukan pada wanita infertile yang menyebabkan gagalnya ovum mencapai tuba maupun gagalnya sperma untuk bertemu ovum di tuba falopi tergantung dari letak penyempitan atau oklusinya di distal atau proksimal dari tuba. ${ }^{10}$ Studi epidemiologi yang dilakukan oleh Masoumi dkk yang meneliti 1200 wanita infertil, $69,5 \%$ menderita infertilitas primer dan 30,5\%nya menderita infertilitas sekunder. Sebanyak 184 pasien (15.4\%) mengalami kelainan tuba, dengan $62 \%$ mengalami kelainan pada kedua tuba dan sisanya mengalami kelainan 
hanya pada salah satu tuba. ${ }^{2}$ Temuan tersebut juga hampir sejalan dengan temuan pada studi ini. Endometriosis terjadi pada 5\%-15\% wanita usia reproduktif dengan gejala dismenor, dyspareunia, nyeri pelvis kroik, pendarahan uterin abnormal, dan infertilitas. Infertilitas yang disebabkan oleh endometriosis terkait dengan adanya salah satu maupun gabungan dari perubahan folikogenesis, disfungsi ovulasi, penurunan streroidogenesis preovulatori dari sel granulosa, fagositoss sperma, sulitnya terjadi fertilisasi, pengeluaran toksik pada masa awal embriogenesis, defek implantasi dan perubahan oosit. ${ }^{8,12}$

Studi ini menunjukan bahwa dari 19 lelaki yang diduga mengalami infertilitas, hampir semuanya dapat terjelaskan alasan dari infertilitasnya dan hanya 1 orang yang tidak dapat dijelaskan alasan infertilitasnya. Hasil analisa sperma menunjukkan bahwa dari 18 orang dengan penyebab infertilitas yang dapat terjelaskan, kelainan sperma terbanyak yang ditemui adalah Oligo Astheno Teratozoospermia $(61,1 \%)$. Kelainan sperma yang paling sedikit ditemukan adalah Oligozoospermia (5,6\%). Infertilitas pada pria merupakan $40-50 \%$ penyebab dari infertilitas dengan 90\% mengalami kelainan pada parameter hitungan sperma. oligozoospermia merupakan jumlah sperma yang $<15$ juta/ml, sedangkan teratozoospermia merupakan adanya kelainan morfologi sperma, dan asthenozoospermia merupakan adanya kelainan motilitas pada sperma, sehingga Oligoasthenoteratozoospermia merupakan kelainan sperma yang mencakup ketiganya. Hasil studi ini serupa dengan studi yang dilakukan oleh Kumar \& Singh dimana sebagian besar dari responden $(51,25 \%)$ mengalami kelainan pada jumlah, pergerakkan dan bentuk sperma, disusul dengan $30,31 \%$ yang mengalami kelainan pada bentuk saja, 22,92\% mengalami kelainan pada motilitas saja dan hanya 3-4\% yang mengalami kelainan pada jumlah sperma saja. ${ }^{13}$ Pola studi seminal yang dilakukan pada pria infertile oleh Jajoo \& Kalyani menemukan bahwa sperma dengan motilitas abnormal terdapat pada $75 \%$ pasien, dan $51 \%$ pasien hanya memiliki $<25 \%$ sperma yang motil. Akan tetapi, sebagian besar dari mereka (41\%) masih memiliki jumlah sperma $<60$ juta per ejakulasi. Hasil sejalan dengan studi ini juga ditunjukkan dengan adanya 52\% pasien yang mengalami kelainan abnormal pada multiple parameter yang dalam hal ini adalah jumlah, morfologi dan pergerakkan. ${ }^{14}$ Hal serupa ditemukan pada studi yang dilakukan Punab dkk dimana pada pasien pria dengan infertilitas hanya ditemukan 3,2\% dengan morfologi sperma yang normal dan $17.2 \%$ dengan motilitas sperma yang normal. Rerata jumlah hitungan sperma pada mereka adalah $12,2+2,5$ juta per mili liter semen. Dari $82.7 \%$ pasien dengan penurunan jumlah sperma, $41,5 \%$ diantaranya tergolong dalam cryptozoospermia (Hitung sperma $<1$ juta/ ejakulasi), $26,1 \%$ tergolong dalam oligozoospermia berat (hitung sperma 1-10 juta/ ejakulasi) dan 22,1\% oligozoospermia moderat (10-38 juta sperma/ ejakulasi). ${ }^{15}$ Proses fertilisasi dapat berhasil pada saat sel sperma dapat mempenetrasi sel telur. Kurangnya jumlah sperma pada setiap ejakulasi menurunkan peluang sperma yang dapat bertahan terhadap keasaman liang vagina dan mencapai tuba falopi untuk melakukan proses konsepsi. Sperma yang tidak dapat bergerak dengan baik juga akan sulit untuk mencapai sel telur. Kelainan morfologis dari sperma akan menyulitkan sperma dalam menembus sel telur dan memasukkan selnya untuk bersatu dengan sel telur. ${ }^{16}$

\section{KETERBATASAN}

Studi ini merupakan studi deskriptif yang dilakukan dengan pendekatan potong lintang dimana pengambilan data hanya dilakukan pada satu waktu tertentu, hal ini memberikan keterbatasan dalam melihat perkembangan data dikarenakan tidak dilakukannya follow up pada setiap responden. Desain deskriptif tidak dapat digunakan untuk melihat faktor risiko dari infertilitas. Keterbatasan waktu, pengambilan sampel dari satu pusat dan pengaksesan rekam medis menyebabkan studi ini memiliki jumlah sampel yang kecil. Perlu dilakukan penelitian lebih lanjut dengan desain analitikal dan sumber sampel yang lebih dari satu pusat perlu dilakukan untuk mendapatkan hasil yang lebih representatif terhadap populasi yang sebenarnya.

\section{SIMPULAN}

Berdasarkan hasil studi ini, maka dapat disimpulkan bahwa faktor penyebbab infertilitas pada perempuan yang paling tinggi adalah kelainan pada tuba yaitu, kedua tuba non patten. Sedangkann penyebab infertilitas paling tinggi pada lakilaki yaitu kelainan pada sperma Oligo Astheno Teratozoospermia berat. Melalui penelitian ini diharapkan dapat meningkatkan informasi dan pengetahuan tentang faktor penyebab infertilitas yang ada pada perempuan dan laki-laki. Perlu ada penelitian lebih lanjut tentang faktor-faktor penyebab infertilitas baik pada perempuan maupun pada laki-laki. 


\section{KONFLIK KEPENTINGAN}

Penulis menyatakan tidak terdapat suatu konflik kepentingan terhadap publikasi dari artikel ini.

\section{PENDANAAN}

Penelitian ini tidak mendapatkan suatu pendanaan yang diberikan oleh pemerintah ataupun lembaga swasta lainnya.

\section{KONTRIBUSI PENULIS}

Konsep penelitian: Ni Wayan Ariati Trisna Dewi, Anom Suardika, Ryan Saktika Mulyana. Pengumpulan data, input data dan pengolahan data: Ni Wayan Ariati Trisna Dewi. Penyusunan naskah Penelitian: Ni Wayan Ariati Trisna Dewi.

\section{ETHICAL CLEARANCE NUMBER:}

1141/UN14.2.2/PD/KEP/2018.

\section{DAFTAR PUSTAKA}

1. Aleida G, Huppelschoten, Noortje T, Peter FJ, van Bommel, Kremer J, Nelen W. Do infertile women and their partners have equal experiences with fertility care. Fertil steril. 2013;99(3). [Diakses 18 Februari 2017].

2. Wardana I., Widianti I., Wirata G. Testosterone increases corpus cavernous smooth muscle cells in oxidative stress-induced rodents (Sprague-Dawley). Bali Medical Journal. 2018. 7(2): 313-322. DOI:10.15562/bmj. v7i2.970.

3. WHO. Infertility. 2013. [Diakses 18 Februari 2017].

4. Roupa, Z., M. Polikandrioti, P. Sotiropoulo, E. Faros, A. Koulouri, G. Wozniak. dan M. Gourni. Causes of infertility in women at reproductive age. 2009. Volume 3. Issue 2. Halaman: 80-87. [Diakses 20 Desember 2017].

5. Saragih CF. Analisa Faktor-Faktor Penyebab Infertilitas di RS Jejaring Depertemen Obgyn FK USU Periode Januari 2012-Desember 2013. (Thesis). Universitas Sumatera Utara. Medan. 2014. [Diakses Tanggal, 25 Desember 2017].
6. Moreton, Cole. "World's first test tube baby louise brown has a child of her own" London: Independent." The 28-yearold, whose pioneering conception by in-vitro fertilization made her famous around the world. The fertility specialist Patrick Steptoe and bob Edwards became the first to successfully carry out IVF by extracting an egg, impregnating it with sperm and planting the resulting embryo back into the mother". (Inggris) [Diakses 2 September 2017]

7. Triwani. Faktor genetic sebagai salah satu penyebab infertilitas pria. Bagian Biologi Medik Fakultas Kedokteran Universitas Sriwijaya, program studi Biomedik program pascasarjana Universitas Sriwijaya Palembang. 2013. [Diakses 2 September 2017]

8. Abrao M., Muzi L., Marana, R. Anatomical causes of female infertility and their management. International Journal of Gyecology and Obstetrics. 2013. 123: 18-24.

9. Miller A., Boyden J., Frey K. Infertility. American Academy of Family Physician. 2007.

10. Bhattacharya S., et. al. Female Infertility. BMJ Clin Evid 2010. 8(11): 312-8

11. Massoumi S., et. al. An epidemiologic survey on the causes of infertility in patiets referred to infertility center in Fatemieh Hospital in Hamadan. Iran J of Rep Med.2015 13(8): 513-6.

12. Macer M., Tyalor H. Endometriosis and Infertility: A review of the pathogenesis and treatment of endometriosis-associated infertility. Obstet Gynecol Clin North Am. 2012. 39(4): 535-549.

13. Kumar N., Singh A. Trends of male factor infertility, an important cause of infertility: A review of literature. J Hum Rreprod Sci. 2015. 8(4): 191-6.

14. Jajoo S., Kalyani K. Prevalence of abnormal semen analysis in patients of infertility at a rural setup in Central India. Int J Reprod Contracept Obstet Gynecol. 2013. 2(2):161-164.

15. Punab M., et. al. Causes of male infertility: a 9-year prospective monocentre study on 1737 patients with reduced total sperm counts. Human Reproduction. 2017. 32(1): $18-31$.

16. Syahputra M. Identification Male Fertility Through Abnormalities Sperm Based Morphology (Teratospermia) using Invariant Moment Method. Journal of Physics. 2017. $4(2): 121-30$.

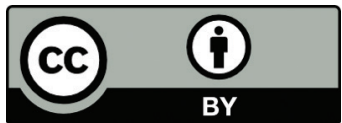

This work is licensed under a Creative Commons Attribution 